\title{
Analisis kebutuhan tenaga kerja front office department di the astari villa \& residence jimbaran bali
}

\author{
Komang Yudi Kharismayana ${ }^{1)}$, Anak Agung Putri Sri' ${ }^{2)}$,Fanny Maharani Suarka ${ }^{3)}$ \\ Fakultas Pariwisata, Jl. Dr. R. Goris No.7, Denpasar \\ komangyudikharismayana@gmail.com ${ }^{1}$
}

\begin{abstract}
Abstrak
Latar belakang masalah penelitianini adalah tingginy a beban kerja pada karyawan sehingga berdampak kepada kua litas pelayanan atau kerja dari FO Supervisor, reception, belldriver, ma upun reservasi ya ng berkurang a dalah kecepatan pelayanan, tingkat kosentrasi kerja, jam kerja yang berlebihan, perhatian kepada tamu akan berkurang sehingga akan membuat ta mu merasa kecewa terhadap pelayanan yang diberikan oleh Front Office Department. Tujuan penelitian iniadalah untuk mengetahui beban kerja dan jumlah tena ga kerja yang semestin ya dibutuhkan Front Office Department di The Astari Villa \& ResidenceJimbaran. Pengumpulan data dalam penelitian inimenggunakan observasi, wa wancara dan kuesioner. Teknik a nalisis y a $\mathrm{ng}$ digunakan a dalah deskritif kualitatif untuk menguraikan mengenaikualifikasi pekerjaan fro nt office department, dan teknikanalisis da ta kuantitatif digunakan untuk menjawab rumusan ma salah dalam penelitian ini.

Ha sil a nalisis da ta menunjukan beban kerja seluruh section yang ada pada Front Office Department di The Astari Villa \& Residence mengalami kekurangan tenaga kerja dengan jumlah tena ga kerja yang berbeda-beda pada setiap sectionya yang berdampak pada kualit as pela yanan y ang diberikan kepada tamu, hal tersebut dapat dilihat dari hasil penyebaran guest coment dimana hasil dari penilain tamu terhadap pelaya nan atau service yang diberikan oleh Front Office Department yang didominasi dengan penila ian cukup. Untuk menin gkatkan pela yanan ke tamu perlu adanya penambahan tenaga kerja pada setiap sectionya diFront Of fice Department. Ja di jumlah tenaga kerja front office department yang semestinya dibutuhkan a dalah 2 orang untuk FO Supervisor, 4 orang untuk reception, 2 orang untuk belldriver dan untuk reservasi hanya membutuhkan 1 orang tenaga kerja dalam menyelesaikan tugas dan tanggung ja wabnya jadi to tal tena ga kerja yang senyatanya dibutuhkan yaitu 9 orang tenaga kerja, tetapi mengingat reservasi section sedang mengalami kekosongan maka perlu adanya perekrutan tenaga kerja baru. Pena mbahan tenaga kerja dimasing-masing section tersebut upaya pekerjaan operasional di Fro $\mathrm{nt}$ Office Department berjalan dengan baik dan mampu memberikan pelayanan kepada tamu de ngan optimal a tau cepat.
\end{abstract}

Kata Kunci: Beban Kerja, Kebutuhan Tenaga Kerja, front office

Abstrack
The background of this research is because the high of workload on the employees that impactthe quality of service or work from FOSpv, reception, belldriver, and reservation. That will cause the decrease theservice rate, the level of work concentration, excessive work hours, and the attention to the guests will be lessened, and it will probably make guests feeldisappoin te d a bou t the services provided by theFront Office Department. The purpose of this study is to discover the workload and the total manpower that should be needed at the Front Office Department at The Astari Villa \& Residence Jimbaran. The methods in collecting the data were by doing observation, interview, and did a questionnaire. In a nalyzing the data was used descriptive qualitative to describe the job of the Front Office Department, and used quantitative methods to a nswer the problem of the study in this research.

The result of the data analysis shows the workload from the entire section of the Front Office Department at The Astari Villa \& Residence Jimbaran encounter with la ck of man power which ha s different quantities of manpower in every section, that decreasing the quality of service to the guests. It could be seen from the guests' comments to the service that provided by the Fro nt Office Department, were dominated with 'Average' rate. To increase the service for the guests, there should be also increased the a mount of manpower in every section of the Front Office Department. The actual total manpower needed are 2 for FO Spv, 4 for reception, 2 for belldriv er, and 1 for the reservation to completing the duties and be responsible for their work. But, due to the emptiness of the reservation section, they need to hire a new manpower to fulfill the section. The 
a dditional of manpower in every section will probably help the operationalduties of Front Of fice Department goes well and could give the guests the best a nd fast service.

Keywords: workload, labor needs, front office

\section{PENDAHULUAN}

Kesempatan untuk bekerja sering kali menjadi permasalahan mendasar yang terjadi di banyak negara di seluruh dunia dan khususnya di Indonesia yang mengalami permasalahan ketenagakerjaan. Di Indonesia permasalahan ketenagakerjaan dipengaruhi oleh beberapa faktor, seperti salah satunya faktor terjadinya kesenjangan antara ketersediaan kesempatan atau lapangan pekerjaan yang kurang dibandingan dengan jumlah angkatan kerja yang ada. Jumlah Tingkat Pengangguran Terbuka (TPT) di Indonesia mengalami peningkatan ataupun penurunan. Pada bulan Februari 2017 mencapai 5,33 persen, dan pada bulan Agustus 2017 mengalami peningkatan sebesar 5,50 persen dan pada tahun berikutnya pada tahun 2018 bulan februari mengalami penurunan sebesar 5.13 persen, jadi perubahan dalam 1 tahun ( Feb 2017-Feb 2018) sebesar -0,20 persen. (BPS 2018). Pencapaian tersebut tentu tidak terlepas dari kuatnya komitmen pemerintah untuk mengurangi pengganguran. Termasuk salah satunya melalui Intruksi Presiden (Inpres) Nomor 9 Tahun 2016 Tentang Revitalisasi SMK dalam rangka peningkatan kualitas dan daya saing sumber daya manusia Indonesia.

Pulau Bali merupakan salah satu daerah tujuan wisata dengan berbagai daya tarik wisatanya seperti wisata alam, buatan maupun budaya yang menjadikan andalan Indonesia untuk mendatangkan wisatawan baik itu dari wisatawan mancanegara maupun wisatawan domestik. Sebagai sebuah daerah tujuan wisata, Bali perlu didukung dengan sarana dan prasarana pokok pariwisata seperti akomodasi perhotelan, travel agent, restaurant, transportasi dan sarana penunjang

lainnya. Semakin banyaknya pertumbuhan pembangunan akomodasi perhotelan dan restaurant yang ada di bali, akan semakin banyak juga tenaga kerja yang akan diserap. Salah satu Kabupaten di Bali yang sangat diminati wisatawan mancanegara dan domestik yang berkungjung ke Bali yaitu Kabupaten Badung. Kabupaten Badung merupakan salah satu kawasan yang memiliki fasilitas, sarana dan prasarana yang menunjang pariwisata serta memiliki daya tarik wisata alam, budaya dan buatan.

Salah satu daerah tujuan wisata yang ada di Kabupaten Badung yang memiliki fasilitas, sarana dan parasarana yang menunjang pariwisata dan tumbuh serta berkembang didalamnya yaitu Jimbaran, Jimbaran merupakan daerah yang mampu menarik minat wisatawan berkunjung, serta banyaknya akomodasi perhotelan seperti hotel berbintang dan non bintang serta villa maupun resort, café dan restoran dengan didukung keindahan alam dan budayanya sehingga wisatawan yang berkunjung dan menginap di Jimbaran mendapatkan kepuasan yang diinginkannya.

Beberapa akomodasi perhotelan yang berada di daerah jimbaran, yang berupa villa salah satunya yaitu The astari Villa \& Residence Jimbaran dimana lokasinya sang at strategis karena lokansinya yang berdekatan dengan pantai jimbaran yang berjarak hanya 5 menit dari pantai jimbaran, sedangkan 25 menit dari bandara I gusti ngurah rai, dan 25 menit dari nusa dua jika ditempuh dengan kendaraan roda dua atau empat serta.di kelilingi oleh villa-villa ternama seperti Four season Resort dan Ayana Resort.

The Astari Villa \& Residence Jimbaran memilki cara tersendiri dalam hal menyambut datangnya wisatawan ke villa yaitu dengan memberikan pelayanan yang maksimal dan ramah sehingga tamu merasa puas dengan pelayanan yang telah diberikan oleh karyawan The Astari Villa \& Residence Jimbaran. Pelayanan yang telah diberikan kepada tamu yang berkunjung atau menginap di The Astari Villa \& Residence Jimbaran tersebut, tentunya sangat membutuhkan kerjasama dari semua pihak yang terlibat dan berkompeten di bidangnya dalam rangka pengembangan villa tersebut. 
Untuk menilai atau mengukur pelayanan yang diberikan oleh karyawan Front Office Dpartment kepadawisatawan yang menginap di The Astari Villa \& Residence Jimbaran dapat dilihat dari guest comentyang telah diberikan oleh pihak villa kepada wisatawan pada saat wisatawan tersebut akancheck out. Adapun hasil guest coment pada Front Office Department di The Astari Villa \& Residence Jimbaran dapat dilihat pada Tabel 1.

Tabel 1 Guest Coment pada Front Office Departmentdi The Astari Villa \& Residence JimbaranPeriode 2018

\begin{tabular}{|c|c|c|c|c|c|c|c|c|c|c|c|c|c|}
\hline \multirow{2}{*}{ Bulan } & \multicolumn{4}{|c|}{ Helpful \& Accommodating } & \multicolumn{4}{|c|}{$\begin{array}{c}\text { Check In \& Check Out } \\
\text { Process }\end{array}$} & \multicolumn{4}{|c|}{ Handling any Request } & \multirow{2}{*}{$\begin{array}{c}\text { Total } \\
\text { Respo } \\
\text { nden }\end{array}$} \\
\hline & $\mathbf{E}$ & $\mathbf{G}$ & $\mathbf{A}$ & $\mathbf{P}$ & $\mathbf{E}$ & $\mathbf{G}$ & A & $\mathbf{P}$ & $\mathbf{E}$ & $\mathbf{G}$ & $\mathbf{A}$ & $\mathbf{P}$ & \\
\hline Januari & 25 & 18 & 5 & 2 & 27 & 20 & 2 & 1 & 30 & 16 & 2 & 2 & 50 \\
\hline Februari & 32 & 33 & 3 & 4 & 34 & 17 & 12 & 9 & 40 & 22 & 7 & 3 & 72 \\
\hline Maret & 30 & 20 & 25 & 2 & 28 & 9 & 37 & 3 & 27 & 14 & 32 & 4 & 77 \\
\hline April & 28 & 20 & 27 & 1 & 28 & 10 & 34 & 4 & 30 & 12 & 32 & 2 & 76 \\
\hline Mei & 17 & 20 & 29 & 8 & 16 & 33 & 15 & 10 & 10 & 24 & 27 & 13 & 74 \\
\hline Juni & 15 & 20 & 26 & 5 & 19 & 25 & 17 & 5 & 12 & 18 & 22 & 12 & 66 \\
\hline Juli & 12 & 20 & 39 & 4 & 12 & 30 & 21 & 12 & 17 & 38 & 15 & 7 & 75 \\
\hline Agustus & 32 & 16 & 40 & 20 & 20 & 13 & 64 & 11 & 10 & 45 & 50 & 3 & 108 \\
\hline September & 22 & 5 & 29 & 3 & 22 & 7 & 25 & 5 & 11 & 12 & 31 & 5 & 59 \\
\hline Oktober & 23 & 6 & 33 & 4 & 29 & 5 & 32 & 2 & 23 & 14 & 28 & 3 & 68 \\
\hline November & 10 & 10 & 19 & 5 & 5 & 22 & 15 & 2 & 8 & 20 & 12 & 4 & 44 \\
\hline Desember & 12 & 16 & 10 & 8 & 17 & 2 & 24 & 3 & 10 & 10 & 22 & 4 & 46 \\
\hline Total & 258 & 204 & 285 & 66 & 257 & 193 & 298 & 67 & 228 & 245 & 280 & 62 & 2.443 \\
\hline Rata-rata & 21,5 & 17 & 23,75 & 5,5 & 21,42 & 16,09 & 24,84 & 5,59 & 19 & 20,42 & 23,34 & 5,17 & 203,59 \\
\hline
\end{tabular}

Sumber: The Astari Villa \& Residence Jimbaran,2018

Keterangan :

$\begin{array}{ll}\mathrm{E} & : \text { Excellent } \\ \mathrm{G} & : \text { Good } \\ \mathrm{A} & : \text { Average } \\ \mathrm{P} & : \text { Poor }\end{array}$

Pada Tabel 1 bahwa guest coment terhadapan pelayanan Front Office Department mendapatkan hasil yang kurang memuaskan dimana didominasi Average (cukup), perlu ada upaya dalam meningkatkan pelayanan yang sudah diberikan menjadi lebih baik lagi.

Untuk menjalankan operasional villa tentu memerlukan tenaga kerja yang handal dan professional di bidangnya masing-masing. Adapun departemen-departemen yang ada di The Astari Villa \& Residence Jimbaran yang tujuannya memudahkan dalam memberikan pelayanan kepada tamu seperti departemen front office, housekeeping, F\&B , SPA, Accounting, Security dan Engineering. Departemen yang difokuskan dalam penelitian ini yaitu front office department yang memiliki fungsi sebagai pusat informasi atau penyalur informasi keseluruh departemen untuk kelancaran operasional dalam memberikan pelayanan yang baik kepada tamu yang menginap. 
Tingginya jumlah kunjungan wisatawan ke villa serta kurangnya tenaga kerja di The Astari Villa \& Residence Jimbaran khususnya di bagian Front Office Department menyebabkan tingginya beban kerja pada karyawan sehingga berdampak kepada kualitas pelayanan atau kerja dari reception, belldriver, maupun reservasi yang berkurang adalah kecepatan pelayanan, tingkat kosentrasi kerja, jam kerja yang berlebihan, perhatian kepada tamu akan berkurang sehingga akan membuat tamu merasa kecewa terhadap pelayanan yang diberikan oleh Front Office Department. Ini yang menyebabkan peneliti ingin meneliti kebutuhan tenaga kerja yang senyatanya dibutuhkan Front Office Department di The Astari Villa \& Residence Jimbaran.

\section{METODE PENELITIAN}

Penulisan laporan ini dimaksudkan untuk memperoleh gambaran jelas tentang kebutuhan tenaga kerja pada Front Office Department di The Astari Villa \& Residence Jimbaran Bali. Bedasarkan hal tersebut lokasi penelitian dilakukan di The Astari Villa \& Residence Jimbaran yang beralamatkan di Jalan Karang Mas Sejahtera gg Kencana Selatan No.1 Jimbaran, Bali dengan nomer telepon +62 3618952065 kode pos : 80361 . Lokasi ini dapat ditempuh sekitar 9,6 km dari Bandara Udara Internasional I Gusti Ngurah Rai dan $34 \mathrm{~km}$ dari pelabuhan sanur. Lokasi villa ini sangat strategis karena terletak di kawasan tourism area di wilayah jimbaran yang berdekatan dengan pantai jimbaran yang dapat ditempuh kurang lebih 4 menit

Untuk memperjelas variabel-variabel yang digunakan dalam penelitian ini dan untuk membatasi permasalahan yang dibahas dalam penelitian ini, maka perlu dijelaskan definisi variabel dalam permasalahan yang akan dibahas. Dalam penelitian ini secara operasional yang dimaksud dengan variabel masalah yang akan diteliti yaitu sebagai berikut :

1) Analisis Beban Kerja ( Work Load Analysis )

Beban kerja merupakan sekumpulan atau sejumlah kegiatan yang harus diselesaikan oleh suatu unit organisasi atau pemegang jabatan dalam jangka waktu tertentu . Di dalam analisis beban kerja terdapat waktu lingkaran kerja yang dipergunakan untuk melaksanakan suatu pekerjaan yang dapat dibagi menjadi empat jenis waktu penyelesaian yaitu :

(1) Waktu Lingkaran (cycle time) adalah waktu yang sungguh-sungguh dipergunakan oleh karyawan Front Office Department di The astari Villa \& Residence Jimbaran untuk bekerja dan sifatnya berulang-ulang, serta berhubungan langsung dengan proses pelayanan penumpang atau tamu.

(2) Waktu Bukan Lingkaran (non-cycle time) adalah waktu yang digunakan oleh karyawan Front Office Department di The astari Villa \& Residence Jimbaran dalam kegiatan-kegiatan yang tidak langsung berhubungan dengan proses produksi.

(3) Waktu Menghilangkan Kelelahan (fatique time) adalah waktu yang digunakan oleh karyawan Front Office Department di The astari Villa \& Residence Jimbaran untuk beristirahat sejenak diantara jam kerja, namun di luar jam istirahat.

(4) Waktu Pribadi (personal time) adalah waktu yang digunakan oleh karyawan Front Office Department di The astari Villa \& Residence Jimbaran untuk keperluan pribadinya.

\section{2) Analisis Kebutuhan Tenaga Kerja (Work Force Analysis)}

Dalam menganalisis kebutuhan tenaga kerja didukung oleh beberapa data yang perlu digunakan untuk perhitungan, yaitu :.

(1) Tingkat Absensi Tenaga Kerjaadalah perbandingan antara hari -hari yang hilang dengan keseluruhan hari yang tersedia untuk bekerja yang dilakukan oleh karyawan Front Office Department di The astari Villa \& Residence Jimbaran, 
sementara ketidakhadiran merupakan suatu kondisi dimana karyawan tidak hadir sesuai dengan yang sudah dijadwalkan dalam periode satu tahun.

(2) Tingkat Perputaran Tenaga Kerja ( Labour Turnover )yang dimaksud adalah perbandingan antara tenaga kerja yang masuk dana tenaga kerja yang berhenti dari suatu perusahaan. Pada penelitian di The Astari Villa \& Residence Jimbaran , sampel yang diambil merupakan aliran masuk dan keluarnya karyawan Front Office Department dalam periode satu tahun.

Tabel 2 Variabel Analisis Beban Kerja dan Analisis Kebutuhan Tenaga Kerja

\begin{tabular}{|c|c|c|}
\hline Variabel & Sub Variabel & Indikator \\
\hline \multirow{4}{*}{$\begin{array}{l}\text { Analisis Beban } \\
\text { Kerja } \\
\text { (WorkLoad } \\
\text { Analysis) }\end{array}$} & $\begin{array}{l}\text { Waktu Lingkaran } \\
\text { (Cycle Time) }\end{array}$ & $\begin{array}{l}\text { Wa ktu yang sungguh-sungguh dipergunakan } \\
\text { oleh karyawan Front Office Department di The } \\
\text { a stari Villa \& Residence Jimbaran untuk } \\
\text { bekerja dan sifatnya berulang-ulang, serta } \\
\text { berhubungan langsung dengan proses } \\
\text { pela yanan penumpang a tau tamu. }\end{array}$ \\
\hline & $\begin{array}{c}\text { Waktu Bukan } \\
\text { Lingkaran } \\
\text { (Non-cycle Time) }\end{array}$ & $\begin{array}{l}\text { Wa ktu yang digunakan oleh karyawan Front } \\
\text { Office Department di The astari Villa \& } \\
\text { Residence Jimbaran dalam kegiatan-kegiatan } \\
\text { yang tidak langsung berhubungan dengan } \\
\text { proses produksi. }\end{array}$ \\
\hline & $\begin{array}{c}\text { Waktu Menghilangkan } \\
\text { Kelelahan (Fatique } \\
\text { Time) }\end{array}$ & $\begin{array}{l}\text { Waktu yang digunakan oleh karyawan Front } \\
\text { Office Department di The astari Villa \& } \\
\text { Residence Jimbaran untuk beristirahat sejenak } \\
\text { diantara jam kerja, namun di luar jam istirahat. }\end{array}$ \\
\hline & $\begin{array}{l}\text { Waktu Priba di } \\
\text { (PersonalTime) }\end{array}$ & $\begin{array}{l}\text { Waktu yang digunakan oleh karyawan } \\
\text { Front Office Department di The astari } \\
\text { Villa \& Residence Jimbaran untuk } \\
\text { keperluan pribadinya. }\end{array}$ \\
\hline $\begin{array}{c}\text { Analisis } \\
\text { Kebutuhan tenaga } \\
\text { kerja } \\
\text { (WorkForce } \\
\text { Analysis) }\end{array}$ & $\begin{array}{l}\text { Analisis Beban Kerja } \\
\text { (Work Load Analysis) }\end{array}$ & $\begin{array}{l}\text { Waktu lingkaran (cycle time), waktu bukan } \\
\text { lingkaran (non-cycle time), wa ktu } \\
\text { menghilangkan kelelahan (fatique time) dan } \\
\text { waktu pribadi (personal time) }\end{array}$ \\
\hline
\end{tabular}




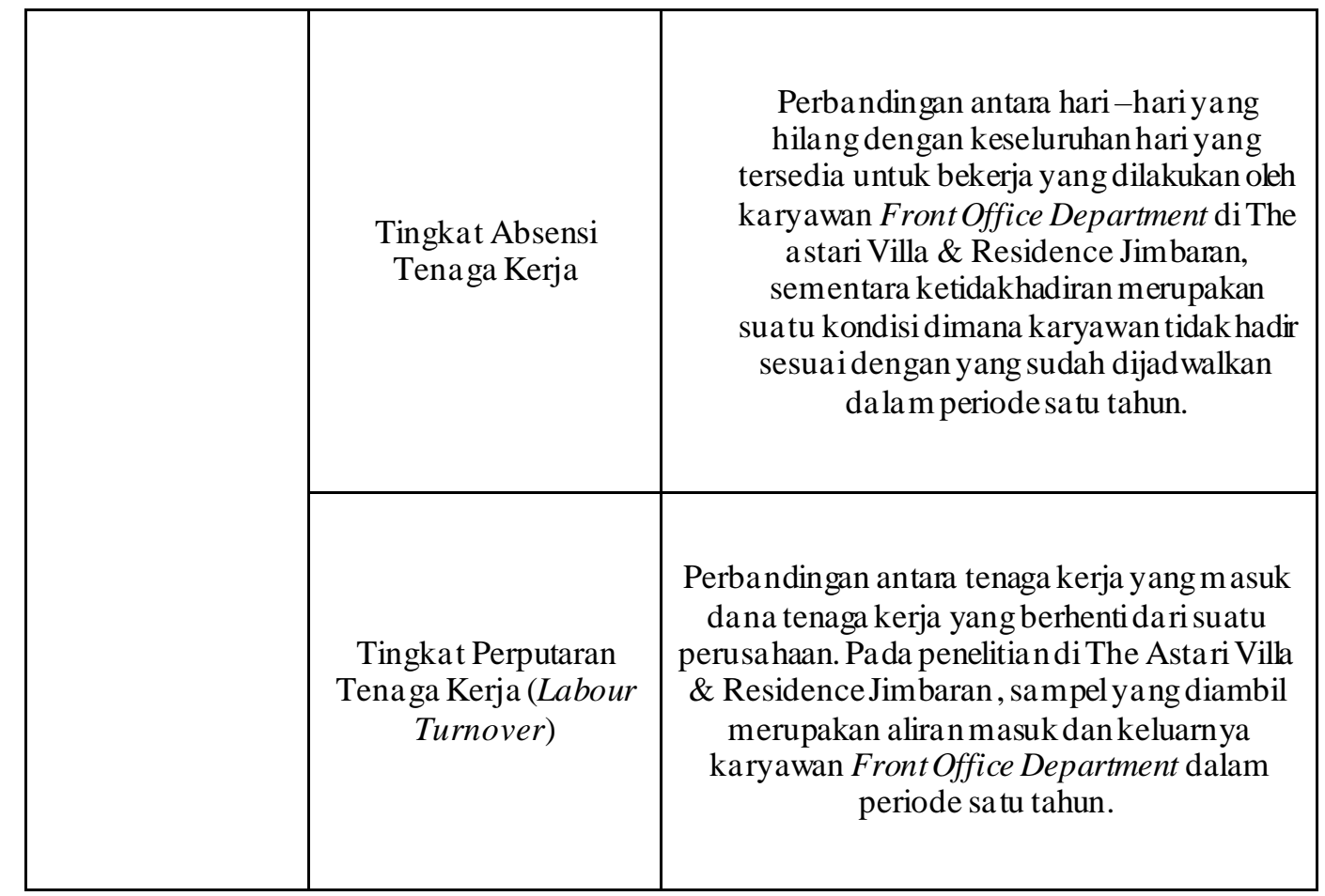

Sumber: Da ta diolah, 2018.

Menurut sumber perolehan data, maka dapat digolongkan menjadi dua jenis data, yaitu.

a Data Kualitatif adalah data yang digambarkan dengan kata-kata atau kalimat yang dipisah-pisahkan menurut kategori untuk memperoleh kesimpulan atau makna sebagai sesuatu yang mendalam (Arikunto, 1991). Dalam penelitian ini yang termasuk data kulitatif antara lain mengenai gambaran umum lokasi penelitian beserta informasi seperti sejarah berdirinya perusahaan, struktur organisasi Front Office Department, uraian tugas dan tanggung jawab Front Office Department, termasuk juga hasil wawancara dengan narasumber dan keterangan-keterangan yang diperoleh terkait analisis kebutuhan tenaga kerja pada Front Office Department di The Astari Villa \& Residence Jimbaran.

b Data Kuantitatif adalah data yang diperoleh dari angka-angka yang telah memiliki batasan yang jelas (Bungin, Burhan. 2015:126). Data kuantitatif dalam laporan ini seperti jumlah tamu yang menginap di The Astari Villa and Residence Jimbaran, jumlah tenaga kerja Front Office Department di The Astari Villa and Residence Jimbaran.

Menurut sumber perolehan data, maka dapat digolongkan menjadi dua sumber data, yaitu.

a Data Primer adalah sumber data yang langsung memberikan data kepada pengumpul data (Sugiyono, 2011:137). Data primer merupakan data yang diperoleh dan dikumpulkan sendiri oleh pneliti dan langsung dari objek yang diteliti seperti jumlah tenaga kerja dan informasi secara mendetail dari seluruh section yang adapada Front Office Department di The Astari Villa \& Residence Jimbaran.

b Data Sekunder adalah sumber yang tidak langsung memberikan data kepada pengumpul data, misalnya lewat orang lain atau bisa berupa dokumen (Sugiyono, 2011:137). Data sekunder merupakan data yang diperoleh dari hasil pengumpulan orang atau melalui suatu instansi, seperti buku-buku atau literature teori dan dokumentasi tenaga kerja Front Office Department di The Astari Villa \& Residence Jimbaran. 
Data yang dipergunakan dalam penelitian ini dikumpulkan dengan cara.

a Observasi merupakan suatu proses yang kompleks, suatu proses yang tersusun dari berbagai proses biologis dan psikologis. Dua di antara yang terpenting adalah proses pengamatan dan ingatan (Sugiyono, 2013:203). Teknik observasi ini dilakukan dengan cara melakukan pengamatan secara langsung kepada objek yang dituju. Dalam penelitian ini observasi yang dimaksud adalah peneliti mengamati langsung secara dekat dalam pelaksanaan tugas karyawanFront Office Department di The Astari Villa \& Residence Jimbaran.

b Wawancara, Menurut (Sugiyono 2014 : 224) pengertian wawancara adalah suatu teknik pengumpulan data yang dilakukan secara terstruktur maupun tidak terstruktur dan dapat dilakukan melalui tatap muka maupun dengan menggunakan jaringan telepon. Adapun 2 jenis informan dalam penelitian ini yatu informasi pangkal dan informasi kunci. Informasi pangkal yakni Resort Manager karena tidak adanya Human Resources Department di The Astari Villa \& Residence Jimbaran, jadi segala informasi mengenai The Astari Villa and Residence langsung dengan Resort Manager dan inform kunci yaitu karyawan di Front Office Department di The Astari Villa \& Residence Jimbaran mengenai waktu penyelesaian pekerjaanya, dan tugas serta tanggung jawab setiap sectionnya masing-masing.

c Angket/Kuesionermerupakan teknik pengumpulan data yang dilakukan dengan cara memberi seperangkat pertanyaan atau pernyataan tertulis kepada responden untuk dijawabnya (Sugiyono, 2013:199). Dalam penelitian ini kuesioner ditunjukan kepada seluruh karyawan Front Office Department di The Astari Villa \& Residence Jimbaran tentang waktu senyatanya yang dibutuhkan untuk menyelesaikan tugas dan kewajibannya.

d Studi Kepustakaanyaitu teknik pengumpulan data dengan melakukan penelahaan terhadap berbagai buku, literature, catatan, serta berbagai laporan yang berkaitan dengan masalah yang ingin dipecahkan (Nasir, 2013).

e Dokumentasi, menurut Sugiyono (2013:240) dokumen merupakan catatan peristiwa yang sudah berlalu. Dokumen bisa berbentuk tulisan, gambar, atau karya-karya monumental dari seorang. Metode ini adalah pengumpulan data berupa foto-foto atau dokumen yang dapat melengkapi data yang tidak dapat diperoleh dalam observasi, wawancara, kuisioner dan studi keputakaan. Dalam penelitian ini dokumentasi bisa berupa seperti foto dan data yang dapat digunakan untuk memperkuat data-data penelitian.

Teknik penentuan informan dalam penelitian ini yaitu teknik purposive sampling. Teknik purposive sampling adalah cara pengambilan informan yang didasarkan atas tujuan tertentu dan atas pertimbangan peneliti (Sundayana, 2009). Informan yang ditetapkan sesuai dengan penelitian yang diteliti dan memiliki kriteria, yaitu mereka yang mendalami informasi sehubungan dengan masalah yang diteliti, mereka diterima oleh berbagai pihak yang terkait dengan kebijakan dan mereka memiliki pengetahuan tentang perusahaan tersebut yang diharapkan mampu memberikan informasi-informasi dalam penelitian ini. Informasi pangkal yang diharapkan mampu memberikan informasiinformasi yang akurat dalam penelitian ini yaitu Ibu Saryati Ayu selaku Resort Manager, karena tidak adanya Human Resources Department di The Astari Villa \& Residence Jimbaran, jadi segala informasi mengenai The Astari Villa and Residence bisa diperoleh melaluiResort Manager dan informan kunci yaitu seluruh karyawan Front Office Department di The Astari Villa \& Residence Jimbaran.

Pengertian teknik sampling menurut Margono (2004) adalah cara untuk menentukan sampel yang jumlahnya sesuai dengan ukuran sampel yang akan dijadikan sumber data sebenarnya, dengan memperhatikan sifat-sifat dan penyebaran populasi agar diperoleh sampel yang representative. Jenis teknik sampling yang digunakan dalam penelitian ini yaitu sampling jenuh/sensus. Sampling jenuh/sensus adalah teknik 
penentuan sampel bila semua anggota populasi digunakan sebagai sampel. Hal ini sering dilakukan bila jumlah populasinya relatif kecil, kurang dari 30 orang dimana semua anggota populasi dijadikan sampel. Sugiyono (2001). Jumlah responden dalam penelitian ini yang berjumlah 6 orang dan terdiri dari beberapa section seperti dari FO Spv berjumlah 1 orang, reception yang berjumlah 3 orang, Belldriver berjumlah 1 orang, dan kemudian reservasi berjumlah 1 orang, akan tetapi berhubung reservasi sectionpada saat ini mengalami kekosongan yang dikarenakan karyawan sebelumnya mengundurkan diri, jadi untuk kuesioner pada reservasi section tersebut akan tetap diberikan kepada mantan karyawan reservasi dengan cara bertemu langsung serta memberikan kuesioner agar mendapatkan informasi dan hasil yang lebih nyata.

Moleong 2002) menjelaskan bahwa analisis data adalah proses mengatur urutan data, mengorganisasikanya ke dalam suatu pola, kategori, dan satuan uraian dasar. Adapun analisis data yang digunakan dalam penelitian ini yaitu :

1) Analisis Deskriptif Kualitatif

Analisis deskritif kualitatif menguraikan hasil dari data yang terkumpul dan disusun secara sistematis yang dijelaskan dengan kalimat agar mudah dimengerti sehingga dapat menggambarkan hasil penelitian. Dalam penelitian ini menguraikan mengenai kualifikasi pekerjaan Front Office Department yang di butuhkan oleh The Astari Villa \& Residence Jimbaran.

2) Analisis Kuantitatif

Menurut Sugiono (2011:243) menyatakan bahwa teknik analisis data kuantitatif yaitu teknik analisis data yang diarahkan untuk menjawab rumusan masalah. Dalam penelitian ini menggunakan rumus statistic untuk menghitung jumlah tenaga kerja Front Office Department yang senyatanya dibutuhkan di The Astari Villa \& Residence Jimbaran. Adapun rumus yang digunakan adalah analisis beban kerja untuk menghitung jumlah tenaga kerja atau karyawan yang semestinya dibutuhkan Front Office Department oleh The Astari Villa \& Residence Jimbaran. Analisis data yang digunakan dalam penelitian ini yaitu :

(1) Analisis Beban Kerja ( Work Load Analysis )

Analisis beban kerja adalah penentuan jumlah tenaga kerja yang diperlukan untuk menyelesaikan suatu pekerjaan dalam jangka waktu tertentu atau penentuan jumlah jam kerja orang yang dibutuhkan untuk menyelesaikan suatu beban kerja dalam periode waktu tertentu, dapat dirumuskan :

\section{Total Man Hours \\ Work Load Analysis = \\ Man Hours per Unit}

Perhitungan ini berdasarkan pada waktu lingkaran (cycle time), waktu bukan lingkaran (non cycle time), waktu menghilangkan kelelahan (fantique time), dan waktu pribadi (personal time).

(2) Analisis Kebutuhan Tenaga Kerja ( Work Force Analysis )

Penentuan jumlah tenaga kerja memperhatikan pada beban kerja, presentase ketidakhadiran dan persentase perputaran tenaga kerja yang dapat dinyatakan dalam rumus sebagai berikut :

WFA = WLA + \% Absenteeism x WLA + \% Labor Turnover $\times$ WLA

Dengan keterangan sebagai berikut:

WFA (Work Force Analysis) : Analisis Kebutuhan Tenaga Kerja

WLA (Work Load Analysis) : Analisis Beban Kerja

$\%$ Absenteeism

: Persentase tingkat perputaran absensi tenaga kerja 
(3) Tingkat Absensi Tenaga Kerja

Dalam penelitian ini yang dimaksud tingkat absensi tenaga kerja adalah tingkat absensi karyawan Front Office Department di The Astari Villa \& Residence Jimbaran. Persentase absensi dapat dirumuskan sebagai berikut :

$\%$ Absenteeism =

Hari Kerja yang Hilang

$100 \%$

\section{Hari Karyawan Bekerja + Hari Karyawan Tidak Bekerja}

Jumlah rata-rata karyawan dalam satu periode atau dalam satu tahun dapat dihitung dengan menggunakan rumus :

= Jumlah Karyawan Awal Periode - Jumlah Karyawan Akhir Periode

\section{2}

Jumlah karyawan awal periode yang dimaksud dalam penelitian ini adalah jumlah tenaga kerja Front Office Department di The Astari Villa \& Residence Jimbaran pada bulan Januari 2018, sementara jumlah karyaw an akhir periode yang dimaksud adalah jumlah tenaga kerja Front Office Department di The Astari Villa \& Residence Jimbaran pada bulan Desember 2018.

(4) Tingkat Perputaran Tenaga Kerja ( Labour Turnover )

Dalam penelitian ini yang dimaksud dengan perputaran tenaga kerja adalah perbandingan antara jumlah pengganti karyawan dalam suatu perusahaan dengan rata-rata karyawan yang terdapat dalam satu periode. Persentase perputaran tenaga kerja (labor turnover) menurut Winaya (1994)dapat dihitung dengan rumus :

\section{Jumlah Pergantian Karyawan \\ \% Perputaran Tenaga Kerja = \\ Rata-rata Karyawan dalam satu periode}

\section{HASIL DAN PEMBAHASAN}

\subsection{Hasil}

Dalam menentukan jumlah tenaga kerja yang dibutuhkan untuk melaksanakan pekerjaan dengan baik dalam periode tertentu (satu tahun), sangat ditentukan oleh jumlah beban kerja dari tugas yang telah dilaksanakan. Dengan adanya beban tugas tersebut maka dapat dilaksanakan beban kerja y ang harus dipikul oleh masing-masing tenaga kerja yang diperlukan, sehingga kekurangan atau kelebihan tenaga kerja dapat dia tasi.

Uraian Waktu Beban Kerja (Work Load Analysis) Front Office Department di The Astari Villa \& Residence Jimbaran.

Untuk mengetahui uraian tugas dan waktu yang senyatanya dibutuhkan oleh Front Office Department di The Astari Villa \& Residence Jimbaran, dapat diketahui dengan ca ra mengalikan jum lah pekerjaan yang diemban oleh karyawan Front Office Department dengan waktu yang digunakan untuk menyelesaikan pekerjaan tersebut.Berikut hasil rekapitulasi dari seluruh kuesioner Front Office Department mengenaijam kerja yang senyatanya dibutuhkan dapat dilihat pada Tabel3. 
Tabel 3 Waktu yang Senyatanya Dibutuhkan Front Office Department Untuk Menyelesaikan Tugas

\begin{tabular}{|c|c|c|c|c|c|c|c|c|c|}
\hline \multirow[b]{2}{*}{ Section } & \multirow[b]{2}{*}{$\begin{array}{c}\text { Jumlah } \\
\text { Respond- } \\
\text { en } \\
\text { (orang) }\end{array}$} & \multicolumn{4}{|c|}{ Analisis Beban Kerja } & \multirow[b]{2}{*}{$\begin{array}{c}\text { Total } \\
\text { (menit) }\end{array}$} & \multirow[b]{2}{*}{$\begin{array}{c}\text { Rata-rata } \\
\text { (menit/ } \\
\text { orang)) }\end{array}$} & \multirow[b]{2}{*}{$\begin{array}{c}\text { Jam kerja } \\
\text { standar } \\
\text { (menit/ } \\
\text { orang) }\end{array}$} & \multirow{2}{*}{$\begin{array}{c}\text { Keleb- } \\
\text { ihan } \\
\text { beban } \\
\text { kerja } \\
\text { (menit/ } \\
\text { orang) }\end{array}$} \\
\hline & & $\begin{array}{l}\text { WL } \\
\text { (meni } \\
\text { t) }\end{array}$ & $\begin{array}{l}\text { WBL } \\
\text { (menit) }\end{array}$ & $\begin{array}{l}\text { WMK } \\
\text { (menit) }\end{array}$ & $\begin{array}{l}\text { WP } \\
\text { (meni) }\end{array}$ & & & & \\
\hline FO Spv & 1 & 75 & 405 & 35 & 35 & 550 & 550 & 420 & 130 \\
\hline Reception & 3 & 255 & 820 & 125 & 135 & 1.335 & 445 & 420 & 25 \\
\hline Belldriver & 1 & 665 & 55 & 40 & 40 & 800 & 800 & 420 & 380 \\
\hline Reservasi & 1 & 210 & 135 & 45 & 40 & 430 & 430 & 420 & 10 \\
\hline
\end{tabular}

Sumber : Data penelitian dari hasil kuesioner Front Office Department di The Astari Villa \& Residence Jimbaran, 2018

Penjelasan :
$\mathrm{WL}=$ Waktu Lingkaran
WBL = Waktu Bukan Lingkaran
WMK = Waktu MenghilangkanLingkaran
WP $=$ Waktu Pribadi

Dapat dilihat Pada Tabel 3, bahwa Padafront office supervisor dengan jumlah karyawan sejumlah 1 orang untuk menyelesaikan tugas waktu lingkaran (cycle time) membutuhkan waktu yaitu 75 menit, waktu bukan lingkaran (non cycle time) membutuhkan waktu yaitu 405 menit, waktu menghilangkan kelelahan (fatique time) membutuhkan waktu yaitu 35 menit dan waktu pribadi (personal time) membutuhkan waktu yaitu 35 menit, jadi total waktu yang senyatanya dibutuhkan front office supervisor untuk menyelesaikan tugasnya yaitu 550 menit, karena jam kerja standar sebesar 420 menit maka front office supervisor memiliki kelebihan beban kerja sebesar 130 menit.. Kemudian reception dengan jumlah karyawan yaitu 3 orang untuk menyelesaikan tugas waktu lingkaran (cycle time) membutuhkan waktu yaitu 255 menit, waktu bukan lingkaran (non cycle time) membutuhkan waktu yaitu 820 menit, waktu menghilangkan kelelahan (fatique time) membutuhkan waktu yaitu 125 menit dan waktu pribadi (personal time) membutuhkan waktu yaitu 135 menit, jadi total waktu yang senyatanya dibutuhkan reception untuk menyelesaikan tugasnya yaitu 1.335 menit,, karena jam kerja standar yaitu 420 menit maka reception memiliki kelebihan beban kerja sebesar 25 menit/orang, sedangkan belldriver dengan jumlah karyawan yaitu 1 orang untuk menyelesaikan tugas waktu lingkaran (cycle time) membutuhkan waktu yaitu 665 menit, waktu bukan lingkaran (non cycle time) membutuhkan waktu yaitu 55 menit, waktu menghilangkan kelelahan (fatique time) membutuhkan waktu yaitu 40 menit dan waktu pribadi (personal time) membutuhkan waktu yaitu 40 menit, jadi total waktu yang senyatanya dibutuhkan belldriver untuk menyelesaikan tugasnya yaitu 800 menit, karena jam kerja standar yaitu 420 menit maka belldriver memiliki kelebihan beban kerja sebesar 380 menit dan pada reservasi untuk menyelesaikan tugas waktu lingkaran (cycle time) membutuhkan waktu yaitu 210 menit, waktu bukan lingkaran (non cycle time) membutuhkan waktu yaitu 135 menit, waktu menghilangkan kelelahan (fatique time) membutuhkan waktu yaitu 45 menit dan waktu pribadi (personal time) membutuhkan waktu yaitu 40 menit, jadi total waktu yang senyatanya dibutuhkan reservasi untuk menyelesaikan tugasnya yaitu 430 menit, karena jam kerja standar yaitu 420 menit maka reservasi memiliki kelebihan beban kerja sebesar 10 menit. 


\subsection{Pembahasan}

Untuk mengetahui jumlah tenaga kerja yang senyatanya dibutuhkan oleh front office department di The Astari Villa \& Residence Jimbaran dapat menggunakan analisis beban kerja, tingkat absensi tenaga kerja dan tingkat perputaran tenaga kerja yang dapat dijelaskan sebagai berikut.

\section{Analisis Beban Kerja ( Work Load Analysis )}

Dengan menggunakan analisis beban kerja maka dapat diketahui jumlah tenaga kerja yang seharusnya dibutuhkan pada periode tertentu yaitu dengan membagi beban kerja Front Office Department pada periode tertentu dengan total jam kerja Front Office Department pada periode tertentu. Satu periode ada 365 hari dimana setiap karyawan Front Office Department bekerja selama 6 hari dalam seminggu. Jadi jumlah hari kerja yang sebenarnya dapat dihitung dengan cara sebagai berikut:

Jumlah hari/Tahun

$$
\text { : } 365 \text { Hari }
$$

Hari libur (day off)

: 53 Hari ( setahun )

Cuti dalam setahun

: 12 Hari ( setahun )

Hari libur nasional

: 14 Hari ( setahun )

Jumlah hari kerja efektif sebernarnya : 286 Hari ( setahun )

Untuk menentukan jumlah tenaga kerja dapat dihitung dengan cara mengalikan jumlah orang atau tenaga kerja dengan total waktu kerja dan jumlah hari dalam setahun. Adapun perhitungan beban kerja Front Office Department di The Astari Villa \& Residence Jimbaran sebagai berikut :

\section{A. Front Office Supervisor.}

Total beban kerja $\quad=1 \times 550 \times 365$

$$
\begin{aligned}
& =200.750 \mathrm{menit} \\
\text { Jumlah kerja efektif } & =7 \times 60 \times 286 \\
& =120.120 \text { menit }
\end{aligned}
$$

Jumlah tenaga kerja Front Office Supervisor di The Astari Villa \& Residence Jimbaran yang dibutuhkan adalah

Total Man Hours

Work load analysis

Man Hours Per Unit

Work Load Analysis $\quad=\frac{200.750}{120.120}$

$=1,67$ orang, di bulatkan menjadi 1 orang

B. Reception

Total beban kerja

Jumlah kerja efektif

$$
\begin{aligned}
& =3 \times 445 \times 365 \\
& =487.275 \text { menit } \\
& =7 \times 60 \times 286 \\
& =120.120 \text { menit }
\end{aligned}
$$

Jumlah tenaga kerja reception di The Astari Villa \& Residence Jimbaran yang dibutuhkan adalah

Total Man Hours

Work load analysis

Man Hours Per Unit

$$
\text { Work Load Analysis } \quad=\frac{487.275}{120.120}
$$


C. Belldriver

$$
=4,05 \text { orang, di bulatkan menjadi } 4 \text { orang }
$$

Total beban kerja $\quad=1 \times 800 \times 365$

$$
\begin{aligned}
& =292.000 \mathrm{menit} \\
\text { Jumlah kerja efektif } & =7 \times 60 \times 286 \\
& =120.120 \mathrm{menit}
\end{aligned}
$$

Jumlah tenaga kerja belldriver di The Astari Villa \& Residence Jimbaran yang dibutuhkan adalah

Total Man Hours

Work load analysis $\quad=$

Man Hours Per Unit

$$
\begin{aligned}
\text { Work Load Analysis } & =\frac{292.000}{120.120} \\
& =2,43 \text { orang, di bulatkan menjadi } 2 \text { orang }
\end{aligned}
$$

D. Reservasi

Total beban kerja

$$
\begin{array}{rl}
\text { Jeban kerja }=1 \times 4 & 430 \times 365 \\
& =156.950 \text { menit } \\
\text { Jumlah kerja efektif } & =7 \times 60 \times 286 \\
& =120.120 \text { menit }
\end{array}
$$

Jumlah tenaga kerja reservasi di The Astari Villa \& Residence Jimbaran yang dibutuhkan adalah

Total Man Hours

Work load analysis $\quad=$

Man Hours Per Unit

$$
\begin{aligned}
\text { Work Load Analysis } & =\frac{156.950}{120.120} \\
& =1,30 \text { orang, di bulatkan menjadi } 1 \text { orang }
\end{aligned}
$$

Berdasarkan perhitungan analisis beban kerja, maka jumlah tenaga kerja yang senyatanya dibutuhkan oleh Front Office Department di The Astari Villa \& Residence Jimbaran dapat dilihat pada Tabel 4.

Tabel 4 Jumlah tenaga kerja Front Office Department yang senyatanya dibutuhkan di The Astari Villa \& Residence Jimbaran

\begin{tabular}{|l|l|l|l|l|}
\hline No & Section & $\begin{array}{l}\text { Tenaga kerja } \\
\text { awal } \\
(\text { orang) }\end{array}$ & $\begin{array}{l}\text { Tambahan } \\
\text { tenaga kerja } \\
\text { (orang) }\end{array}$ & $\begin{array}{l}\text { Total tenaga kerja } \\
\text { senyatanya dibutuhkan } \\
\text { (orang) }\end{array}$ \\
\hline 1 & FO Spv & 1 & 1 & 2 \\
\hline 2 & Reception & 3 & 1 & 4 \\
\hline 3 & Belldriver & 1 & 1 & 2 \\
\hline 4 & Reservasi & 0 & 1 & 1 \\
\hline Total & & 5 & 4 & 9 \\
\hline
\end{tabular}

Sumber: Da ta diolah, 2018 
Pada Tabel 4 bahwa jumlah tenaga kerja awal Front Office Department di The Astari Villa \& Residence Jimbaran berjumlah 5 orang dan setelah dilakukan perhitungan dengan menggunakan analisis beban kerja, maka didapat hasil yaitu tambahan tenaga kerja pada beberapa section di Front Office Department, pada Front Office Supervisor adanya tambahan tenaga kerja sejumlah 1 orang sehingga tenaga kerja yang senyatanya dibutuhkan berjumlah 2 orang, kemudian pada reception adanya tambahan tenaga kerja sejumlah 1 orang sehingga tenaga kerja yang senyatanya dibutuhkan berjumlah 4 orang, sedangkan pada belldriver adanya tambahan tenaga kerja sejumlah 2 orang sehingga tenaga kerja yang senyatanya dibutuhkan berjumlah 3 orang, dan pada reservasi tidak terjadi penambahan tenaga kerja dimana tenaga kerja yang senyatanya dibutuhkan han ya 1 orang. Jadi total tenaga kerja yang senyatanya dibutuhkan Front Office Department di The Astari Villa \& Residence Jimbaran berjumlah 9 orang.

Tingkat Absensi Tenaga Kerja

Tenaga kerja dalam suatu perusahaan tidak dapat selalu hadir atau bekerja, kemungkinan absen akan dapat saja terjadi baik itu izin, sakit, alpha atau alasan lainnya. Disamping itu adanya kemungkinan penambahan atau pengaruh jumlah karyawan karena alasan tertentu, oleh karena itu tenaga kerja yang senyatanya dibutuhkan dapat diketahui. Adapun jumlah ketidakhadiran Front Office Department di The Astari Villa \& Residence Jimbaran dapat dilihat pada Tabel 5.

Tabel 5 Jumlah ketidakhadiran Front Office Department di The Astari Villa \& Residence Jimbaran

\begin{tabular}{|l|l|l|l|l|l|}
\hline Bulan & Hari Kerja & $\begin{array}{l}\text { Tenaga } \\
\text { Kerja } \\
\text { (orang) }\end{array}$ & $\begin{array}{l}\text { Jumlah Hari } \\
\text { Kerja }\end{array}$ & $\begin{array}{l}\text { Hadir } \\
\text { (orang) }\end{array}$ & $\begin{array}{l}\text { Tidak Hadir } \\
\text { (orang) }\end{array}$ \\
\hline Januari & 26 & 6 & 156 & 133 & 23 \\
\hline Februari & 24 & 6 & 144 & 126 & 18 \\
\hline Maret & 26 & 5 & 130 & 108 & 22 \\
\hline April & 25 & 5 & 125 & 107 & 18 \\
\hline Mei & 26 & 4 & 104 & 87 & 17 \\
\hline Juni & 25 & 4 & 100 & 82 & 18 \\
\hline Juli & 26 & 3 & 78 & 59 & 19 \\
\hline Agustus & 26 & 5 & 130 & 111 & 19 \\
\hline September & 25 & 5 & 125 & 107 & 18 \\
\hline Oktober & 26 & 5 & 130 & 113 & 17 \\
\hline November & 25 & 4 & 100 & 84 & 16 \\
\hline Desember & 26 & 5 & 130 & 113 & 17 \\
\hline Total & 306 & 57 & 1,452 & 1,230 & 222 \\
\hline Sumber: Resore & 26 & Residence Jimbaran, & \\
\hline
\end{tabular}

Sumber: Resort Manager The Astari Villa \& Residence Jimbaran, 2018

Jumlah hari kerja yang hilang

$\%$ Absensi $=$

Hari karyawan bekerja + Hari karyawan tidak bekerja

$\%$ Absensi $=\frac{222}{1.230+222} \times 100 \%$

$\%$ Absensi $=\frac{222}{1.452} \times 100 \%$ 
$\%$ Absensi $=0,15 \%$ per tahun, $0,0125 \%$ per bulan

Bedasarkan perhitungan diatas dapat disimpulkan yaitu tingkat ketidakhadiran karyawan Front Office Department dalam sebulan sebesar 0,0125\% dan 0,15\% per tahunnya.

\section{Tingkat Perputaran Tenaga Kerja (Labour Turnover)}

Untuk mengetahui tingkat perputaran tenaga kerja pada suatu perusahaan dapat dikatakan baik atau tidak, dapat diketahui dari jumlah tenaga kerja yang masuk atau keluar dalam satu periode pada Front Office Department. Adapun jumlah tingkat perputaran tenaga kerja Front Office Department di The Astari Villa \& Residence pada tahun 2018 dapat dilihat pada Tabel 6.

Tabel 6 Jumlah Perputaran Tenaga Kerja Front Office Department di The Astari Villa \& Residence

\begin{tabular}{|l|l|l|l|}
\hline Bulan & $\begin{array}{l}\text { Tenaga Kerja } \\
\text { (orang) }\end{array}$ & $\begin{array}{l}\text { Masuk } \\
\text { (orang) }\end{array}$ & $\begin{array}{l}\text { Keluar } \\
\text { (orang) }\end{array}$ \\
\hline Januari & 6 & 0 & 0 \\
\hline Februari & 6 & 0 & 1 \\
\hline Maret & 5 & 0 & 0 \\
\hline April & 5 & 0 & 1 \\
\hline Mei & 4 & 0 & 0 \\
\hline Juni & 4 & 0 & 1 \\
\hline Juli & 3 & 2 & 0 \\
\hline Agustus & 5 & 0 & 0 \\
\hline September & 5 & 0 & 0 \\
\hline Oktober & 5 & 0 & 1 \\
\hline November & 4 & 1 & 0 \\
\hline Desember & 5 & 0 & 0 \\
\hline Total & 57 & 3 & 4 \\
\hline
\end{tabular}

Sumber: Resort Manager The Astari Villa \& Residence Jimbaran, 2018

Persentase tingkat perputaran tenaga kerja Front Office Department adalah : Jumlah tenaga kerja yang keluar dalam satu periode

$\%$ Perputaran tenaga kerja $=$ $\mathrm{x} 100 \%$

Rata-rata tenaga kerja dalam satu periode

$$
\begin{aligned}
& =\frac{1}{57 / 12} \times 100 \% \\
& =\frac{1}{4,75} \times 100 \% \\
& =21,05 \% \text { per tahun } \\
& =1,75 \% \text { per bulan }
\end{aligned}
$$

Bedasarkan perhitungan diatas maka dapat disumpulkan bahwa jumlah perputaran tenaga kerja dalam satu tahun yaitu $21,05 \%$. 
Jumlah ideal Front Office Department yang senyatanya dibutuhkan dapat dihitung dengan menggunakan rumus :

Work Force Analysis

$$
\begin{aligned}
= & \text { Work Load Analysis }+(\% \text { Absenteism x Work Load } \\
& \text { Analysis }+\% \text { Labour Turnover } \times \text { Work Load Analysis }) \\
= & 9+(0,0125 \% \times 9+1,75 \% \times 9) \\
= & 9+(0,001125+0,1575) \\
= & 9+(0,158625) \\
= & 9,158625 \\
= & 9 \text { orang (dibulatkan) }
\end{aligned}
$$

Bedasarkan analisis beban kerja dan analisis kebutuhan tenaga kerja dapat diketahui bahwa jumlah ideal yang senyatanya dibutuhkan Front Office Department di The Astari Villa \& Residence Jimbaran Bali yaitu 9 orang. Sedangkan pada saat ini hanya terdapat total 5 karyawan Front Office Department . Maka terjadi kekurangan 4 orang karyawan. Berikut akan dijelaskan perbandingan tenaga kerja Front Office Department yang lama (sebelum dianalisis) dan tenaga kerja Front Office Department yang baru (setelah dianalisis) dapat dilihat pada Tabel 7.

Tabel 7 Tenaga Kerja yang Senyatany a dibutuhkan Front Office Department di The Astari Villa \& Residence Jimbaran

\begin{tabular}{|l|l|l|l|l|l|l|}
\hline No & Section & $\begin{array}{l}\text { Tenaga Kerja } \\
\text { Awal } \\
\text { (orang) }\end{array}$ & $\begin{array}{l}\text { Waktu yang } \\
\text { Senyatanya } \\
\text { Dibutuhkan } \\
\text { (menit/ } \\
\text { orang) }\end{array}$ & $\begin{array}{l}\text { Jam } \\
\text { Kerja } \\
\text { Standar } \\
\text { (menit/or } \\
\text { ang) }\end{array}$ & $\begin{array}{l}\text { Kelebihan } \\
\text { bebankerja } \\
\text { (menit/ } \\
\text { orang) }\end{array}$ & $\begin{array}{l}\text { Tenaga Kerja } \\
\text { Yang Senyatanya } \\
\text { Dibutuhkan } \\
\text { (orang) }\end{array}$ \\
\hline 1 & Fo Spv & 1 & 550 & 420 & 130 & 2 \\
\hline 2 & Reception & 3 & 445 & 420 & 25 & 4 \\
\hline 3 & Belldriver & 1 & 800 & 420 & 380 & 2 \\
\hline 4 & Reservasi & 0 & 430 & 420 & 10 & 1 \\
\hline & Total & 5 & & & & 9 \\
\hline
\end{tabular}

Sumber: Da ta diolah, 2018

Pada Tabel 7 bahwa jumlah tenaga kerja awal Front Office Department di The Astari Villa \& Residence Jimbaran yaitu berjumlah 5 orang, setelah dilakukan analisis beban kerja dan analisis kebutuhan tenaga kerja mendapatkan hasil yang berbeda pada setiap sectionnya. Pada Front Office Supervisor yang memiliki tenaga kerja awal berjumlah 1 orang memerlukan waktu yang senyatanya dibutuhkan untuk menyelesaikan tugas yaitu selama 550 menit sedangkan jam kerja standar yang sudah ditetapkan oleh manajemen The Astari Villa \& Residence Jimbaran yaitu 420 menit/orang, dimana terdapat kelebihan beban kerja sebanyak 130 menit dan diperlukan tenaga kerja yang senyatanya dibutuhkan sejumlah 2 orang.

Kemudian pada reception yang memiliki tenaga kerja awal berjumlah 3 orang rata-rata memerlukan waktu yang senyatanya dibutuhkan untuk menyelesaikan tugas yaitu selama 445 menit/orang sedangkan jam kerja standar yang sudah ditetapkan oleh manajemen The Astari Villa \& Residence Jimbaran yaitu 420 menit/orang, dimana terdapat kelebihan beban kerja sebanyak 25 menit dan diperlukan tenaga kerja yang senyatanya dibutuhkan sejumlah 4 orang. 
Sedangkan pada belldriver yang memiliki tenaga kerja awal berjumlah 1 orang memerlukan waktu yang senyatanya dibutuhkan untuk menyelesaikan tugas yaitu selama 800 menit sedangkan jam kerja standar yang sudah ditetapkan oleh manajemen The Astari Villa \& Residence Jimbaran yaitu 420 menit/orang, dimana terdapat kelebihan beban kerja sebanyak 380 menit dan diperlukan tenaga kerja yang senyatanya dibutuhkan sejumlah 2 orang.

Tetapi pada reservasi, saat ini tidak memiliki tenaga kerja karena tenaga kerja sebelumnya mengundurkan diri sehingga yang dijadikan responden untuk mengetahui tugas reservasi dan waktu yang senyatanya dibutuhkan dalam menyelesaikan tugas sebagai reservasi diberikan kepada mantan reservasi yang sudah mengundurkan diri tersebut. Adapun waktu yang senyatanya dibutuhkan untuk menyelesaikan tugas reservasi yaitu selama 430 menit sedangkan jam kerja standar yang sudah ditetapkan oleh manajemen The Astari Villa \& Residence Jimbaran yaitu 420 menit/orang, dimana terdapat kelebihan beban kerja hanya 10 menit sehingga tenaga kerja yang senyatanya dibutuhkan hanya 1 orang. Jadi total tenaga kerja yang senyatanya dibutuhkan Front Office Department yaitu 9 orang.

\section{KESIMPULAN}

Berdasarkan hasil analisis, maka dapat disimpulkan bahwa hasil analisis kebutuhan tenaga kerja Front Office Department di The Astari Villa \& Residence Jimbaran, Bali adalah sebagai berikut.

1 Untuk mengetahui beban kerja Front Office Department di The Astari Villa \& Residence Jimbaran dapat diketahui dari uraian tugas masing-masing section pada Front Office Department dengan menggunakan analisis beban kerja (work load analysis) dengan menggunakan empat jenis waktu penyelesaian yaitu waktu lingkaran (cycle time), waktu bukan lingkaran (non cycle time), waktu menghilangkan kelelahan (fatique time) dan waktu pribadi (personal time). Pada front office supervisor dengan jumlah karyawan sejumlah 1 orang untuk menyelesaikan tugas waktu lingkaran (cycle time) membutuhkan waktu yaitu 75 menit, waktu bukan lingkaran (non cycle time) membutuhkan waktu yaitu 405 menit, waktu menghilangkan kelelahan (fatique time) membutuhkan waktu yaitu 35 menit dan waktu pribadi (personal time) membutuhkan waktu yaitu 35 menit, jadi total waktu yang senyatanya dibutuhkan front office supervisor untuk menyelesaikan tugasnya yaitu 550 menit. Kemudian reception dengan jumlah karyawan yaitu 3 orang untuk menyelesaikan tugas waktu lingkaran (cycle time) membutuhkan waktu yaitu 255 menit, waktu bukan lingkaran (non cycle time) membutuhkan waktu yaitu 820 menit, waktu menghilangkan kelelahan (fatique time) membutuhkan waktu yaitu 125 menit dan waktu pribadi (personal time) membutuhkan waktu yaitu 135 menit, jadi total waktu yang senyatanya dibutuhkan reception untuk menyelesaikan tugasnya yaitu 1.335 menit. sedangkan belldriver dengan jumlah karyawan yaitu 1 orang untuk menyelesaikan tugas waktu lingkaran (cycle time) membutuhkan waktu yaitu 665 menit, waktu bukan lingkaran (non cycle time) membutuhkan waktu yaitu 55 menit, waktu menghilangkan kelelahan (fatique time) membutuhkan waktu yaitu 40 menit dan waktu pribadi (personal time) membutuhkan waktu yaitu 40 menit, jadi total waktu yang senyatanya dibutuhkan belldriver untuk menyelesaikan tugasnya yaitu 800 menit dan pada reservasi untuk menyelesaikan tugas waktu lingkaran (cycle time) membutuhkan waktu yaitu 210 menit, waktu bukan lingkaran (non cycle time) membutuhkan waktu yaitu 135 menit, waktu menghilangkan kelelahan (fatique time) membutuhkan waktu yaitu 45 menit dan waktu pribadi (personal time) membutuhkan waktu yaitu 40 menit, jadi total waktu yang senyatanya dibutuhkan reservasi untuk menyelesaikan tugasnya yaitu 430 menit. 
2 Untuk mengetahui kebutuhan tenaga kerja yang senyatanya dibutuhkan Front Office Department di The Astari Villa \& Residence Jimbaran dapat diketahui dengan menggunakan analisis beban kerja dan analisis kebutuhan tenaga kerja (analisis beban kerja, Tingkat absensi tenaga kerja dan tingkat perputaran tenaga kerja ), maka didapat hasil yaitu adanya tambahan tenaga kerja pada beberapa section di Front Office Department. Pada Front Office Supervisor adanya tambahan tenaga kerja sejumlah 1 orang sehingga tenaga kerja yang senyatanya dibutuhkan berjumlah 2 orang, kemudian pada reception adanya tambahan tenaga kerja sejumlah 1 orang sehingga tenaga kerja yang senyatanya dibutuhkan berjumlah 4 orang, sedangkan pada belldriver adanya tambahan tenaga kerja sejumlah 2 orang sehingga tenaga kerja yang senyatanya dibutuhkan berjumlah 3 orang, dan pada reservasi tidak terjadi penambahan tenaga kerja dimana tenaga kerja yang senyatanya dibutuhkan hanya 1 orang. Jadi total tenaga kerja yang senyatanya dibutuhkan Front Office Department di The Astari Villa \& Residence Jimbaran berjumlah 9 orang. Jumlah tenaga kerja awal Front Office Department yaitu berjumlah 5 orang dan sehingga perlu adanya tambahan tenaga kerja baru yang berjumlah 4 orang.

\section{Ucapan Terima kasih}

Dalam pelaksanaan penyusunan laporan ini, penulis mendapat banyak bantuan, bimbingan, dan arahan dari berbagai pihak. Oleh sebab itu, dalam kesempatan ini penulis ingin menyampaikan ucapan terima kasih yang tulus kepada Dr. Drs. I Nyoman Sunarta, M.Si., selaku Dekan Fakultas Pariwisata Universitas Udayana. Ibu Dra. Anak Agung Putri Sri, M.Si selaku Koordinator Program Studi Diploma IV Pariwisata. Ibu Ni Ketut Arismayanti, SST.Par.,M.Par selaku Pembimbing Akademik yang sudah memberikan arahan selama penulis menempuh pendidikan di Fakultas Pariwisata Universitas Udayana. Ibu Dra. Anak Agung Putri Sri, M. selaku pembimbing I yang sudah membimbing dengan baik dan penuh kesabaran. Ibu Fanny Maharani Suarka, SST.Par.,M. Par selaku pembimbing II yang sudah membimbing dengan baik dan penuh kesabaran. Ibu Dr. Ni Putu Ratna Sari, SST.Par., M. Par.dan Ibu Luh Gede Leli Kusuma Dewi, S.Psi.,M.Par selaku penguji yang sudah membantu dalam proses penyempurnaan skripsi ini. Kedua orang tua dan saudara yang telah mendoakan, memberikan dukungan dan kasihnya selama penulis menempuh pendidikan sehingga penulis selalu semangat dalam proses penyelesaian pendidikan. Teman-teman mahasiswa Diploma IV Pariwisata Fakultas Pariwisata Universitas Udayana angkatan 2014, atas motivasi dan dukungan yang diberikan selama proses penyelesaian laporan ini.

\section{DAFTAR PUSTAKA}

Ardana, I Komang., Mujiati, Ni Wayan., \& Utama, I Wayan Mudiartha. 2012. Manajemen Sumber Daya Manusia. Yogyakarta: Graha Ilmu.

Ariasa, Yogi. 2015. "Analisis Kebutuhan Tenaga Kerja Reservasi di Prama Sanur Beach Bali”. Laporan Akhir. Denpasar: Program Studi Diploma IV Pariwisata Fakultas Pariwisata Universitas Udayana.

Arikunto, Suharsimi, 1991. Metodologi Penelitian. Jakarta: Rineka Cipta. 2006. Prosedur Penelitian Suatu Pendekatan Praktik. Jakarta:

\section{Rineka Cipta.}

Bagyono. 2008, Teori dan Praktik Hotel Front Office. Bandung: Penerbit Alfabeta. 2010. Hotel Front Office. Bandung: Alfabeta.

Bungin, Burhan. 2015, Metodologi Penelitian Kualitatif: Depok, Rajagrafindo Pustaka.

Darmawan, Agus. 2015. "Analisis Kebutuhan Tenaga Kerja Guest Relations di Hotel Rimba Jimbaran Bali”. Laporan Akhir. Denpasar: Program Studi S1 Industri Perjalanan Wisata Fakultas Pariwisata Universitas Udayana. 
Dwipayana, Made Adi Krisna. 2016. Strategi Pemasaran Bali Nyuh Gading Villa Di Kerobokan Kabupaten Badung. Denpasar: Prodi Magister Kajian Pariwisata Universitas Udayana.

Folino.F, David. 2013. Manajemen Karyawan. (Cetakan I). Jakarta: Platinum.

Gaffar, Abdul Ruskhan. 2007. Kompas Bahasa Indonesia. Jakarta: Grasindo.

Handoko. 2011. Manajemen. Edisi Kedua. Yogyakarta: BPFE.

Hasibuan, Malayu S.P. 2012. Manajemen Sumber Daya Manusia. Jakarta: Bumi Aksara.

Aksara. 2013. Manajemen Sumber Daya Manusia. Jakarta: Bumi

Husnan. 2011. Manajemen Personalia, Edisi IV, Yogyakarta: Anggota Ikapi.

Jewell, L. N. \& Siegall, M., (1998). Psikologi Industri/Organisasi Modern: Psikologi Penerapan Untuk Memecahkan Berbagai Masalah Di Tempat Kerja, Perusahaan, Industri, Dan Organisasi, ed-2, hal 529. Jakarta: Arcan.

Komarudin, A. 1996. Dasar-Dasar Manajemen Investasi. Rineka Cipta. Jakarta.

Lexy Moleong, Metode Penelitian Kualitatif (Bandung: PT. Remaja Rosda Karya, 2002). Mahendra, Krishna. 2016. "Analisis Kebutuhan Tenaga Kerja Bellboy Section pada Front Office Department di Hotel Inna Grand Bali Beach Resort \& Spa Sanur Bali”. Laporan Akhir. Denpasar: Program Studi Diploma IV Pariwisata Fakultas Pariwisata Universitas Udayana.

Margono. 2004.Metodologi Penelitian Pendidikan. Jakarta: Rineka Cipta.

Martoyo, Susilo. 2002. Manajemen Sumber Daya manusia. Edisi Kedelapan. BPFE. Yogyakarta.

Mathis. L. Robert dan Jackson. H. John. 2000. Manajemen Sumber Daya Manusia. Jakarta: Salemba Empat.

2001. Manajemen Sumber Daya Manusia.

Jakarta: Salemba Empat.

Moekijat. 2004. Manajemen Tenaga Kerja dan Hubungan Kerja. Bandung: Pioner Jaya.

Nazir, Moh. (2013). Metode Penelitian. Bogor: Ghalia Indonesia

Peraturan Menteri Pariwisata dan Ekonomi Kreatif Republik Indonesia, Nomor: PM.106/PW.006/MPEK/2011, tentang Sistem Penanganan Hotel.

Perspektif PHRI Bali yang mengacu pada Kepmen Budpar No.KM.3/HK/001/MKP/2/2002. Pengertian Tentang Villa.

Putri, Emmita Devi Hari. 2016. Pengantar Akomodasi dan Restoran. Deepublish.

Rezawati, Suci. 2013.Analisis Labour Turnover pada PT. Delta Internusa Pekanbaru. Pekanbaru: Universitas Islam Negeri Sultan Syarif Kasim Riau.

Rivai, Veithzal. 2004. Manajemen Sumber Daya Manusia Untuk Perusahaan. Jakarta: Murai Kencana.

2009. Manajemen Sumber Daya Manusia Untuk Perusahaan Dari Teori ke Praktik. Jakarta: Raja Grafindo Persada.

Robbins, S. P. 2001. Organizational behavior: Concepts, controversies, and applications third edition.USA: Prentice Hall Inc.

Robbins, Stephen P. dan Judge, Timothy A. 2009. Organizational Behavior. USA: Pearson International Edition Prentice-Hall.

Ronald, Sukwadi dan Milkha, Meliana. 2014. Faktor-Faktor yang Mempengaruhi Kinerja dan Turnover Intention Karyawan Usaha Kecil Menengah. Jurnal Rekayasa Sistem Industri Vol.3 No.1.

Sambodo, Agus., dan Bagyono. 2010. Dasar-dasar Kantor Depan Hotel. Yogyakarta: Andi.

Sastrohadiwiryo, B Suswanto. 2003. Manajemen Tenaga Kerja Indonesia, Edisi 2. Jakarta: PT. Bumi Aksara.

Simamora, Henry. 1995. Manajemen Sumber Daya Manusia. Yogyakarta: Bagian Penerbitan STIE YKPN.

Simamora, Henry. 2004. Manajemen Sumber Daya Manusia. Yogyakarta: STIE YKPN. 


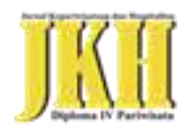

S. P, Hasibuan, Malayu. 2013. Manajemen Sumber Daya Manusia. Jakarta: PT Bumi Aksara.

Sugiarto, Endar. 2000. Operasi Kantor Depan. Jakarta: PT Gramedia Pustaka Utama.

Sugiyono. 2001. Metode Penelitian, Bandung: CV Alfabeta.

2011. Metode Penelitian Kuantitatif, Kualitatif dan R\&D. Bandung: Afabeta 2013. Metodelogi Penelitian. Bandung: Alvabeta.

2013.Metode Penelitian Kuantitatif, Kualitatif, $R \& D$, Bandung: CV. Alfabeta.

2014. Metode Penelitian Pendidikan Pendekatan Kuantitatif, Kualitatif Dan $R \& D$. Bandung: Alfabeta.

Sulastiyono, Agus. 2011. Manajemen Penyelenggaraan Hotel. Seri Manajemen Usaha Jasa Sarana Pariwisata dan Akomodasi. CV. Alfabeta.

Sumarsono, Sony. 2003. Ekonomi Manajemen Sumber Daya Manusia dan Ketenagakerjaan. Yogyakarta: Graha Ilmu.

Susila, Rama. 2017. "Analisis Kebutuhan Tenaga Kerja Waiter dan Waitress di W Bali Seminyak". Laporan Akhir. Denpasar: Program Studi Diploma IV Pariwisata Fakultas Pariwisata Universitas Udayana.

Tarmoezi, Trizno dan Heldin Manurung. 2000. Profesional Hotel Front Liner. Jakarta: Visipro.

Utama. 2001. Manajemen Sumber Daya Manusia. Denpasar: Universitas Udayana.

Undang-Undang Dasar 1945 No. 13 Tahun 2003 Pasal 1 Ayat 2 Tentang Ketenagakerjaan.

Walker, James W. 1992. Human Resources Strategy. Singapura: Mc Graw Hill Book Co.

Wardiyanta. 2010. Metode Penelitian Pariwisata. Yogyakarta: Andi.

Widodo, Putra. 2010.Analisis faktor-faktor yang mempengaruhi tingkat labour turnover pada Hotel Tasia Ratu Pekanbaru. Pekanbaru: Universitas Islam Negeri Sultan Syarif Kasim Riau.

Winaya, Kuna. 1994. Manajemen Sumber Daya Manusia(lanjutan), edisi III, Denpasar: Universitas Udayana. 